\title{
Short Note \\ DEVELOPMENT AND APPLICATION OF AN INNOVATIVE ELECTRICAL GASTROMETER
}

\author{
Siddartha Sankar Biswas
}

Gobindopur, Sreepur, Magura, Bangladesh

email: siddarthasankar@yahoo.com

\begin{abstract}
A simple electrical gastrometer has been innovated and developed based on short circuit current produced by a voltaic cell comprising of two dissimilar metallic electrodes in a probe on which a specific volume of saliva is placed. This has been used to take data from 388 normal subjects and 622 subjects with gastric acidity problems to various degrees, assessed by the author in his capacity as a village doctor. A grading scheme was also developed to categorise the condition of the disorder based on the intensity of discomfort. A good correlation has been observed between the assessed degree of gastric acidity and the currents produced in this gastrometer. Thus this low cost device may be useful in diagnosing gastric problems. Furthermore, treatment given to these patients based on this estimation also produced relief in majority of cases.
\end{abstract}

\section{INTRODUCTION}

As a trainee rural doctor the author noticed that many patients complain of acidity problems, i.e., problems related to digestion. However, no equipment capable of measuring such conditions of acidity quantitatively is available in the hospitals of Bangladesh, and treatment is carried out based on the idea of the doctor only. This sometimes leads to complications, and even death may result in certain cases. Equipment to measure $\mathrm{pH}$ in the Esophagus are available in advanced countries [1], but these are expensive, and have not found much in use in Bangladesh. This experience led the author to develop an innovative electrical gastrometer based on current produced by a fixed volume of saliva in a voltaic cell. Measurements were taken on many patients using this gastrometer and the results indicate the efficacy of this instrument. Treatment given to these patients based on this estimation also produced relief in majority of cases.

\section{METHODS}

This locally innovated gastrometer is an electrical device having two electrodes of dissimilar metals with a small separation between them in the probe. The associated electronic circuit measures the current produced by the probe when a small measured volume of saliva from the patient is placed on it. The potential developed by the saliva in this device will depend on its acidity which in turn is expected to have a relationship to the acidity in the stomach. The resulting short circuit current is measured to give a quantitative measurement which is expected to be related to the acidity of the saliva. This measurement is expected to have a contribution from the conductivity of saliva as well.

This locally designed gastrometer was used to measure the saliva of about 388 normal volunteers of different age, and were used to establish a normal range. Next the device was used to monitor patients with gastric problems, coming to the clinic of the author. A total of 622 patients were studied to date. The patients were divided into groups based on reported symptoms and the measurements obtained using the new device were recorded. A grading scheme was also developed to categorise the condition of the disorder based on the intensity of discomfort. The patients were also given treatment based on the values of currents obtained using the gastrometer and the success obtained (in \% of patients) were also recorded. 


\section{RESULTS AND DISCUSSIONS}

Table 1 gives the results of the study on 388 normal subjects of different age groups.

Table 1. Normal current values for different age groups

\begin{tabular}{|l|c|c|c|c|c|c|c|}
\hline $\begin{array}{l}\text { Age } \\
\text { group, yrs }\end{array}$ & $<2$ & $2-5$ & $5-15$ & $15-30$ & $30-45$ & $45-60$ & $>60$ \\
\hline $\begin{array}{l}\text { Current, } \\
\mu \mathrm{A}\end{array}$ & $22-28$ & $22-29$ & $23-31$ & $23-31$ & $23-29$ & $23-29$ & $24-28$ \\
\hline
\end{tabular}

It may be seen that the values for all ages are very close, there does not seem to be any significant difference. Therefore, current values between $22 \mu \mathrm{A}$ and $31 \mu \mathrm{A}$ may be taken to correspond to normal healthy value, measured using the prototype gastrometer developed and fabricated in the present work.

The results of the study on patients complaining of dyspepsia, heart-burn, acidity and abdominal pain are given in Table 2. The grading into categories and the treatment given to the patient, which included prescription of diets and medications, are also given in the table. For comparison, current data on 388 normal subjects are also included in the table.

It may be seen from Table 2 that a large deviation in the current is produced by saliva of patients, compared to the normal subjects. This shows the efficacy of the newly developed device. Besides, the current values increase for increased levels of discomfort, which is reasonable to expect. Furthermore, the treatment regime that has been tried in this study seem to have succeeded in alleviating the discomfort in a majority of the patients also seem to suggest that the discomforts were really due to gastric acidity problems.

Table 2: Study using the prototype Gastrometer, total no. of subjects $=1010$ (including normal)

\begin{tabular}{|c|c|c|c|c|c|}
\hline Symptoms & $\begin{array}{l}\text { Number } \\
\text { of cases }\end{array}$ & $\begin{array}{l}\text { Gastrometer } \\
\text { reading, } \mu \mathrm{A}\end{array}$ & Grading & $\begin{array}{l}\text { Treatment: Diet \& } \\
\text { Medicine }\end{array}$ & Success \\
\hline $\begin{array}{l}\text { All time dyspepsia, } \\
\text { Occasional heart-burn }\end{array}$ & 90 & $14-19$ & B- & $\begin{array}{l}\text { Diet: Khichuri' } \\
\text { Sour items, Bread. } \\
\text { Med: Domperdone, } \\
1+1+1\end{array}$ & $85 \%$ \\
\hline Occasional Dyspepsia & 68 & $19-23$ & A- & $\begin{array}{l}\text { Diet: Khichuri' } \\
\text { Sour items, Bread. }\end{array}$ & $87 \%$ \\
\hline Normal & 388 & $22-31$ & $\mathrm{~A}$ & No treatment & ------ \\
\hline $\begin{array}{l}\text { Reduced bowel } \\
\text { movement, occasional } \\
\text { feeling of acidity }\end{array}$ & 200 & $31-36$ & $\mathrm{~A}+$ & $\begin{array}{l}\text { Med: Antacyd } \\
\text { Plus, } 1+0+1\end{array}$ & $81 \%$ \\
\hline $\begin{array}{l}\text { Continuous feeling of } \\
\text { acidity, Antacid taken }\end{array}$ & 140 & $36-41$ & $\mathrm{~B}+$ & $\begin{array}{l}\text { Med: Ranitidine } \\
\text { 150mg, } 1+0+1\end{array}$ & $83 \%$ \\
\hline $\begin{array}{l}\text { Occasional abdominal } \\
\text { pain, even after taking } \\
\text { acidity tablets. }\end{array}$ & 112 & $41-50$ & $\mathrm{C}+$ & $\begin{array}{l}\text { Med: Omeprazole } \\
20 \mathrm{mg} ., 1+0+1 . \\
\text { Domperdone, } \\
1+1+1\end{array}$ & $76 \%$ \\
\hline $\begin{array}{l}\text { Abdominal pain even } \\
\text { after taking antacid } \\
\text { tablets. Emergency } \\
\text { treatment needed in } \\
\text { cases. }\end{array}$ & 12 & $>50$ & $\mathrm{D}+$ & No Treatment & ------- \\
\hline
\end{tabular}




\section{CONCLUSIONS}

A quantitative measurement of gastric function can improve the diagnosis and treatment of gastric acidity related disorders. However, before the present invention of an electrical Gastrometer there was no method of doing these measurements routinely in a clinical set up, particularly in the Third World. All treatment were given based on the perception of the clinician from a verbal report of the discomfort and symptoms. This has resulted in failures, even death. Therefore the present invention of an electrical Gastrometer will have a significant role in the diagnosis and therapy of gastric problems.

The idea of using saliva in measuring gastric acidity is reasonable, and has been shown to work in practice through the present study. The measurement is also simple. It just needs a few drops of saliva to perform the measurements, and may be performed by rural health workers with a little training. The equipment design, involving electronic circuitry, is also low cost and affordable to the health workers in a Third World situation. There are no consumables, and as such the measurements require no cost except that of the manpower. The equipment is small and portable and may form a standard item in the brief case carried by a rural health worker.

Therefore, widespread use of this new invention will have a great impact on the treatment of gastric problems, which is one of the most common medical problems.

\section{Acknowledgements}

To Professor K Siddique-e Rabbani for writing the paper in a presentable form in English from draft notes by the author.

\section{REFERENCES}

1. M. M. Trifonov, Devices and Probes for Intracavitary pH Monitoring, Biomedical Engineering, Vol. 37, No. 3, 2003, pp. 156-160. 